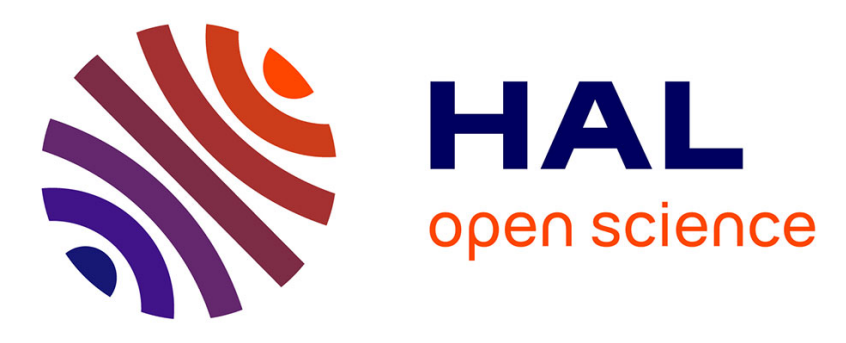

\title{
Photo-regulation in microphytobenthos from intertidal mudflats and non-tidal coastal shallows
}

\author{
Filip F. Pniewski, Paulina Biskup, Iwona Bubak, Pierre Richard, Adam \\ Latala, Gérard Blanchard
}

\section{- To cite this version:}

Filip F. Pniewski, Paulina Biskup, Iwona Bubak, Pierre Richard, Adam Latala, et al.. Photoregulation in microphytobenthos from intertidal mudflats and non-tidal coastal shallows. Estuarine, Coastal and Shelf Science, 2015, 152, pp.153-161. 10.1016/j.ecss.2014.11.022 . hal-01096631

\section{HAL Id: hal-01096631 \\ https://hal.science/hal-01096631}

Submitted on 17 Dec 2014

HAL is a multi-disciplinary open access archive for the deposit and dissemination of scientific research documents, whether they are published or not. The documents may come from teaching and research institutions in France or abroad, or from public or private research centers.
L'archive ouverte pluridisciplinaire HAL, est destinée au dépôt et à la diffusion de documents scientifiques de niveau recherche, publiés ou non, émanant des établissements d'enseignement et de recherche français ou étrangers, des laboratoires publics ou privés. 


\section{elsevier_YECSS_4596}

\section{Photo-regulation in microphytobenthos from intertidal mudflats and non-tidal coastal shallows}

Filip F. Pniewskia, *

filip.pniewski@ug.edu.pl

Paulina Biskupa

Iwona Bubak ${ }^{\mathrm{a}}$

Pierre Richard

Adam Latała

Gerard Blanchard $^{\mathrm{b}}$

aInstytut Oceanografii, Uniwersytet Gdański, Al. Piłsudskiego 46, 81-378 Gdynia, PotandPolska

'Littoral, Environnement et Sociétés (LIENSs), Institut du Littoral et de l'Environnement, UMR 7266 CNRS-Université de La Rochelle, 2 rue Olympe de Gouges, 17000 La Rochelle, France

${ }^{*}$ Corresponding author.

\section{Abstract}

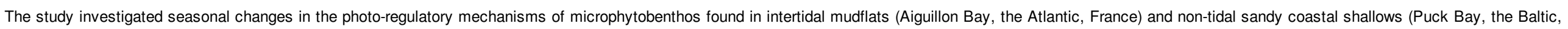

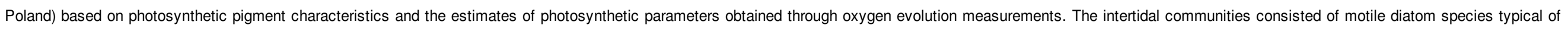

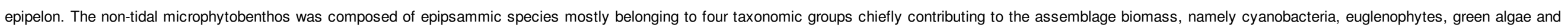

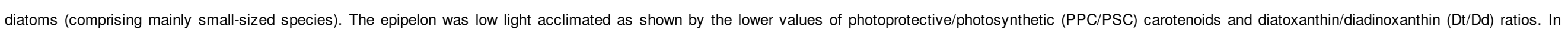

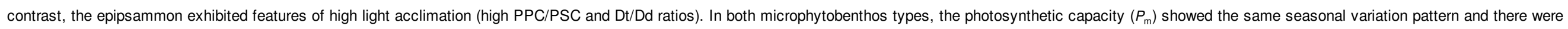

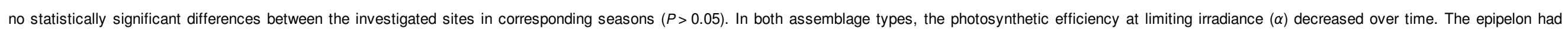

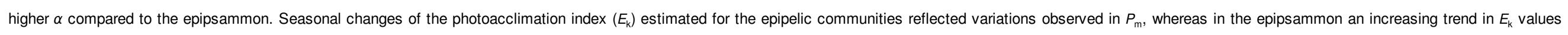

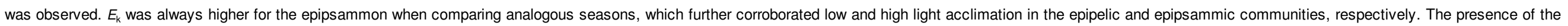

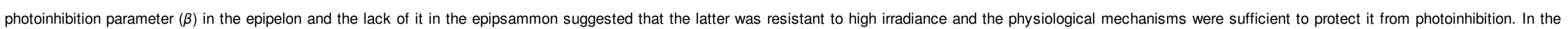

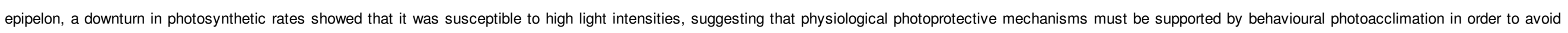
damaging light influence.

Keywords: microphytobenthos; photoacclimation; photosynthesis; photosynthetic pigments; Aiguillon Bay; Baltic Sea

\section{Introduction}

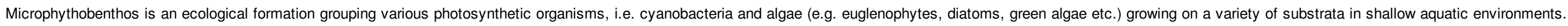

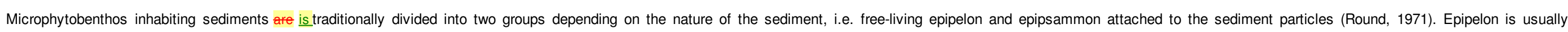

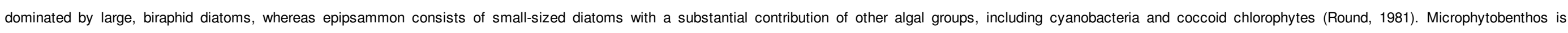

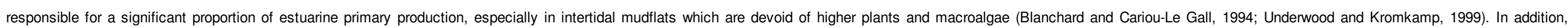

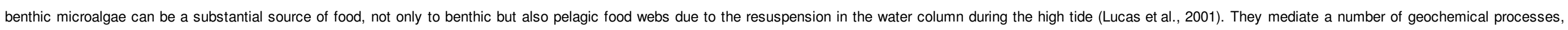




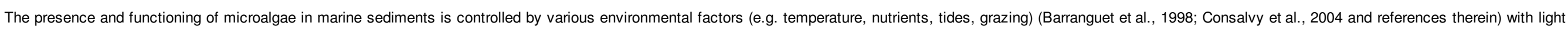

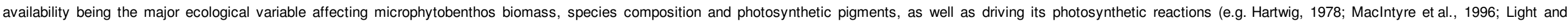

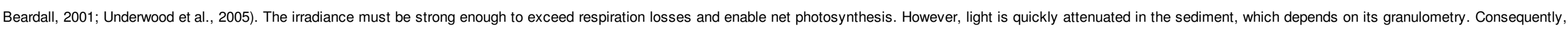

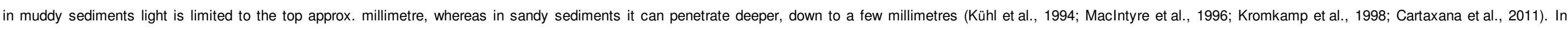
addition, light intensity varies within an extremely wide range and it is the fastest changing factor (Kühl et al., 1994). Therefore, it requires from microphytobenthos a complex adaptive response.

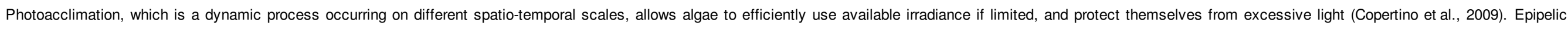

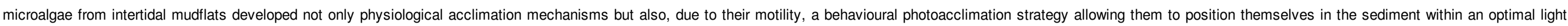

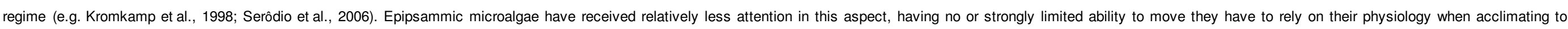

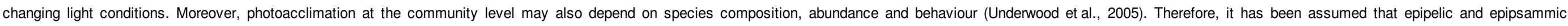
assemblages exhibit different photo-regulatory and adaptive strategies (Jesus et al., 2009).

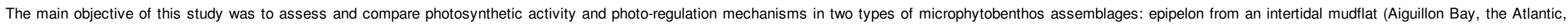
France) and epipsammon from non-tidal sandy coastal shallows (Puck Bay, the Baltic, Poland) across the seasons.

\section{Materials and methods}

\subsection{Research areas, sampling and algal suspension preparation}

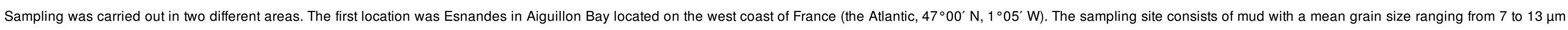

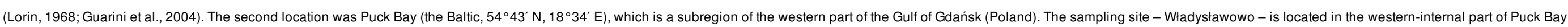
and the bottom sediments of this part of the bay are dominated by fine sands with a narrow zone of medium sands along the coast (Jankowska and Łęczyński, 1993 ). At the sampling site $69 \%$ particles were between 250 and $500 \mu \mathrm{m}$.

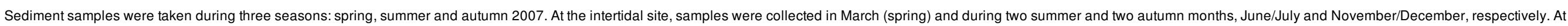

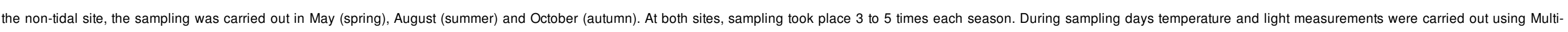

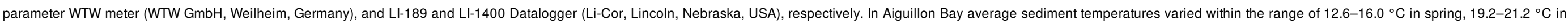

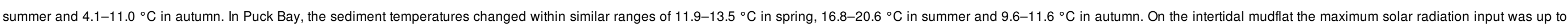

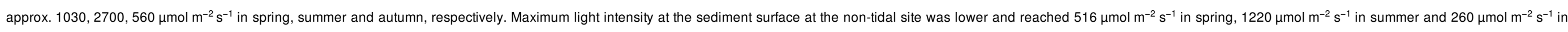
autumn. The measured temperatures and light values reflected their seasonal variation patterns.

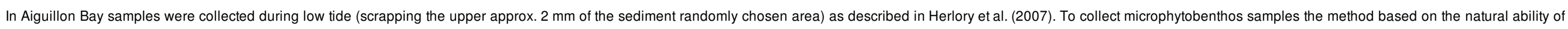

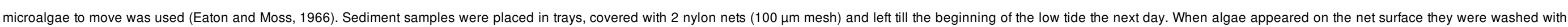

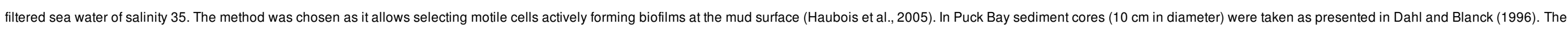

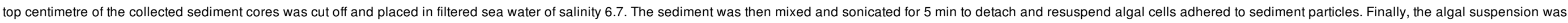

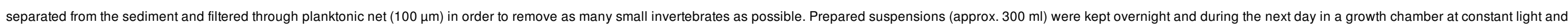
temperature conditions; low light intensity of approx. $50 \mu \mathrm{mol} \mathrm{m}^{-2} \mathrm{~s}^{-1}, 14: 10 \mathrm{~L}: \mathrm{D}$ photoperiod and temperatures corresponding to those observed in the environment, i.e. approx. $10^{\circ} \mathrm{C}$ (autumn), $15^{\circ} \mathrm{C}$ (spring) or $20^{\circ} \mathrm{C}$ (summer).

\subsection{Species composition}

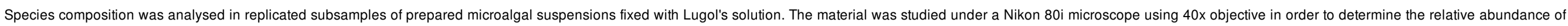

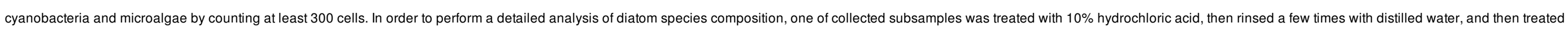

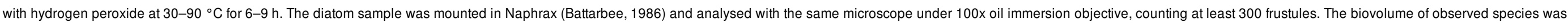
calculated according to Olenina et al. (2006). The biomass (wet weight) of each taxonomic group was derived based on an assumption of a plasma density of $1 \mathrm{~g} \mathrm{~cm}^{-3}$ across all taxa (HELCOM, 2013). 


\subsection{Photosynthetic pigment analyses}

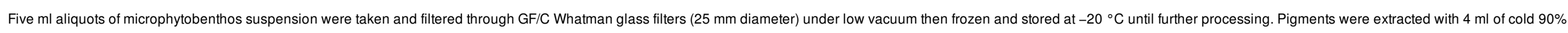

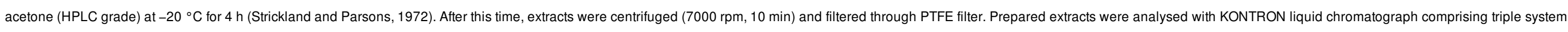

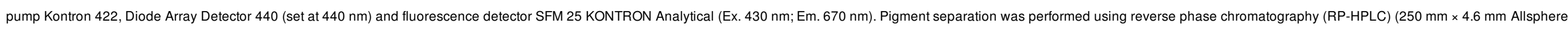

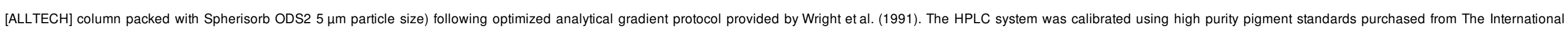

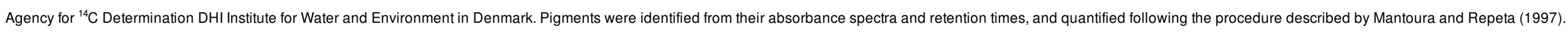

\subsection{Photosynthesis-irradiance (P-E) curves}

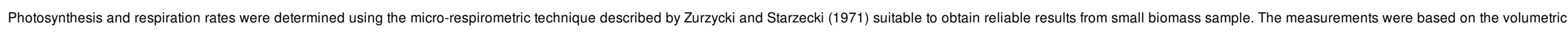
principle, i.e. a change in gas volume under constant pressure.

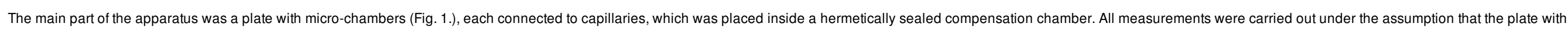

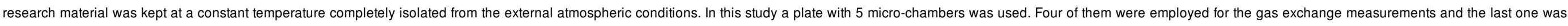

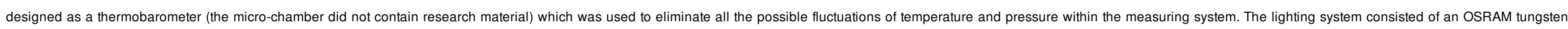

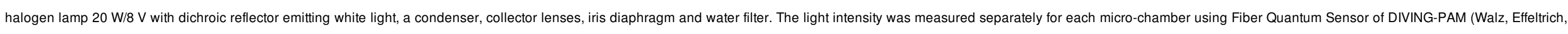

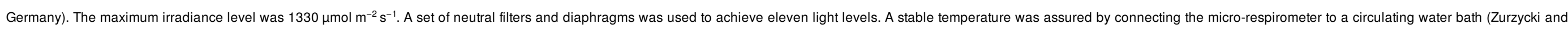
Starzecki, 1971). Gas exchange measurements were performed at temperatures of $20^{\circ} \mathrm{C}, 15^{\circ} \mathrm{C}$ and $10{ }^{\circ} \mathrm{C}$ for summer, spring and autumn benthic communities, respectively.

A

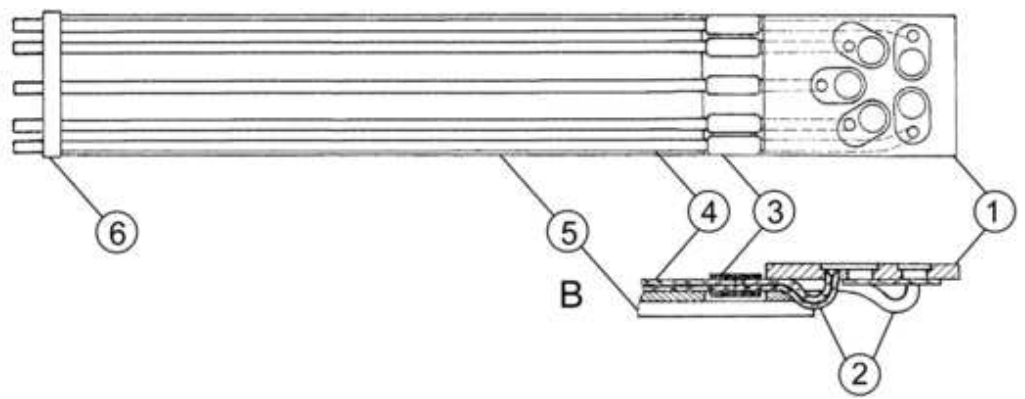

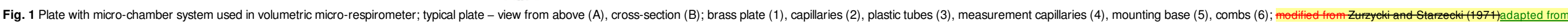

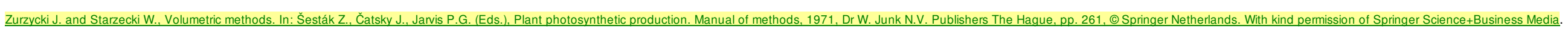

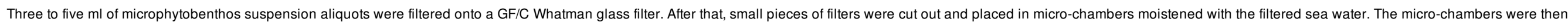

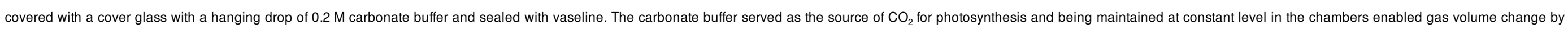

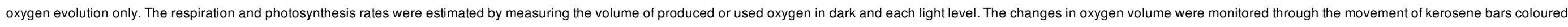

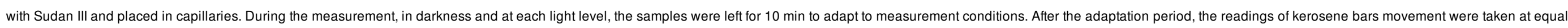

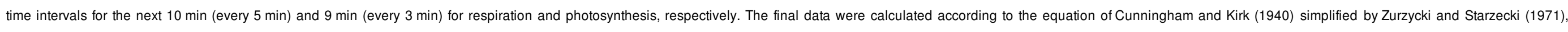

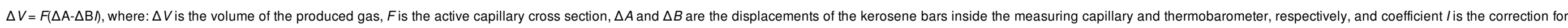

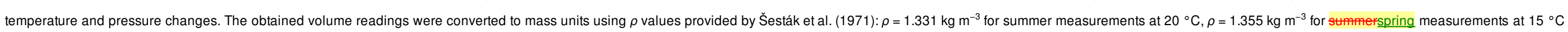
and $\rho=1.378 \mathrm{~kg} \mathrm{~m}^{-3}$ for autumn measurements at $10^{\circ} \mathrm{C}$. Calculated photosynthesis and respiration rates were then normalized per total chlorophyll $a(\mathrm{Chl} a)$ concentration.

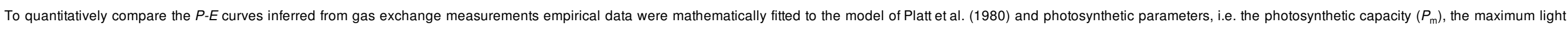
utilization coefficient $(\alpha)$, the light saturation index $\left(E_{\mathrm{k}}\right)$, the light saturation point $\left(E_{\mathrm{m}}\right)$ and the photoinhibition parameter $(\beta)$ were estimated (Sakshaug et al., 1997). 


\section{elsevier_YECSS_4596}

\subsection{Statistical analyses}

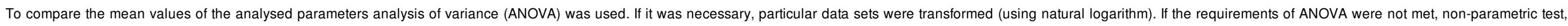

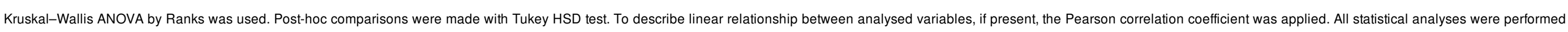
using Statistica 10 (StatSoft Inc., USA).

\section{Results}

\subsection{Microscopic observations}

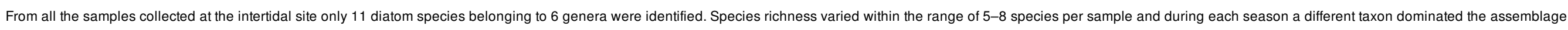

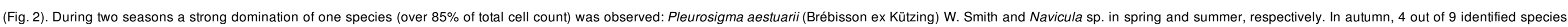

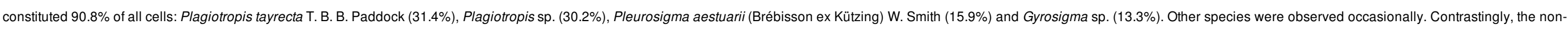

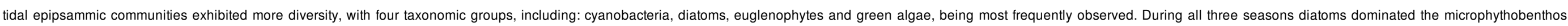

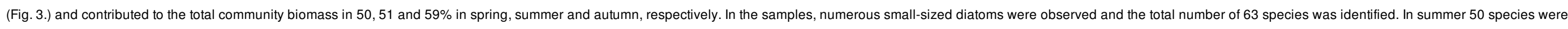

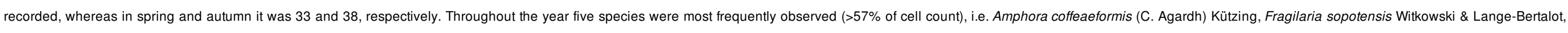

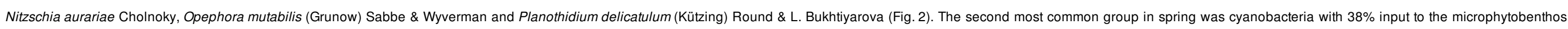

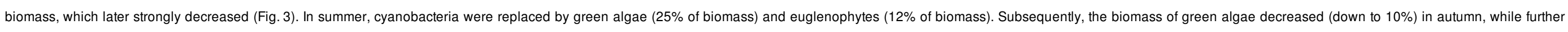
increase of euglenophytes biomass, up to $17 \%$, was observed (Fig. 3).

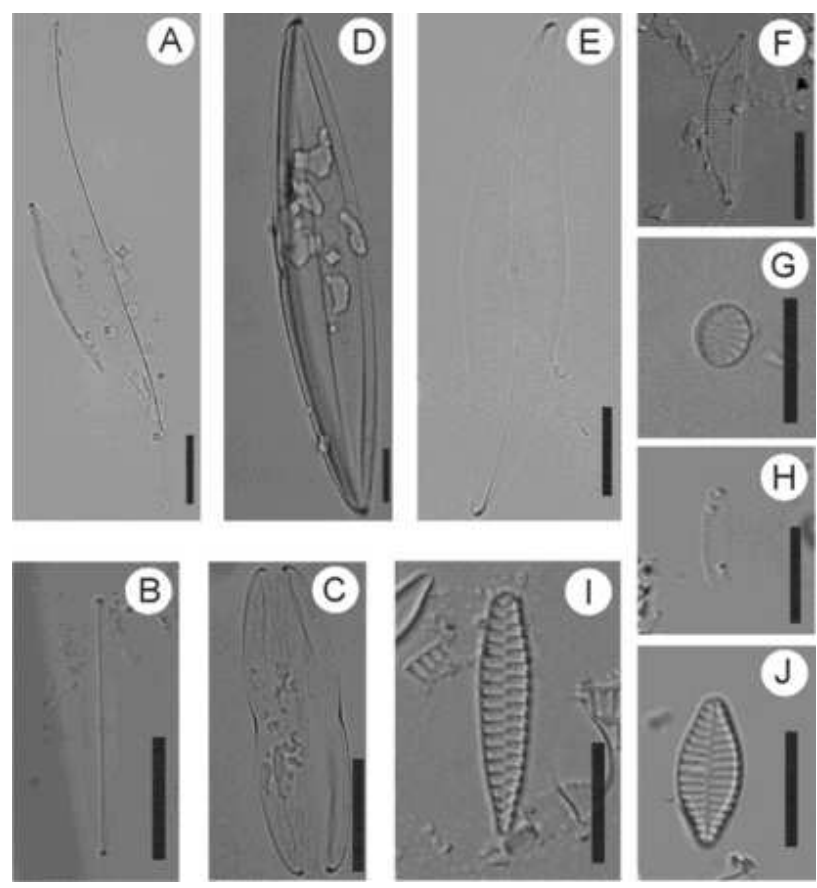

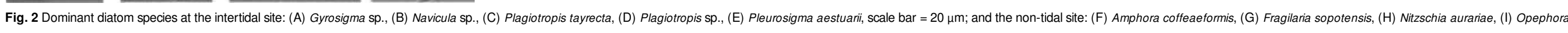
mutabilis and $(\mathrm{J})$ Planothidium delicatulum, scale bar $=10 \mu \mathrm{m}$. 


\section{elsevier_YECSS_4596}

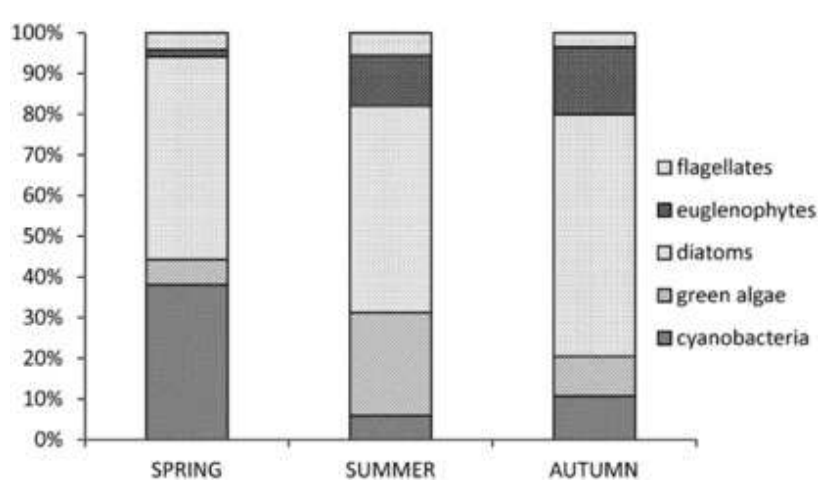

Fig. 3 Seasonal changes in the contribution of algal groups to the total community biomass in microphytobehtos from the coastal shallows of the Puck Bay.

\subsection{Pigment analyses}

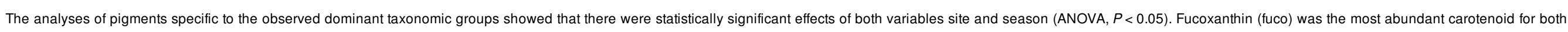

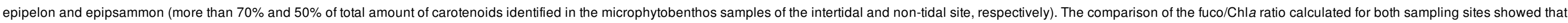

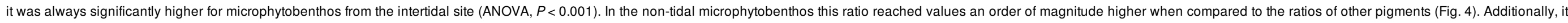

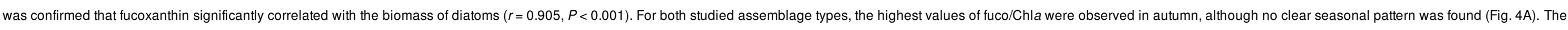

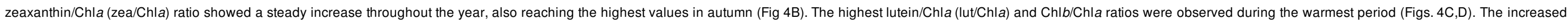

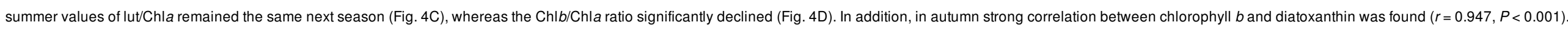




\section{elsevier_YECSS_4596}

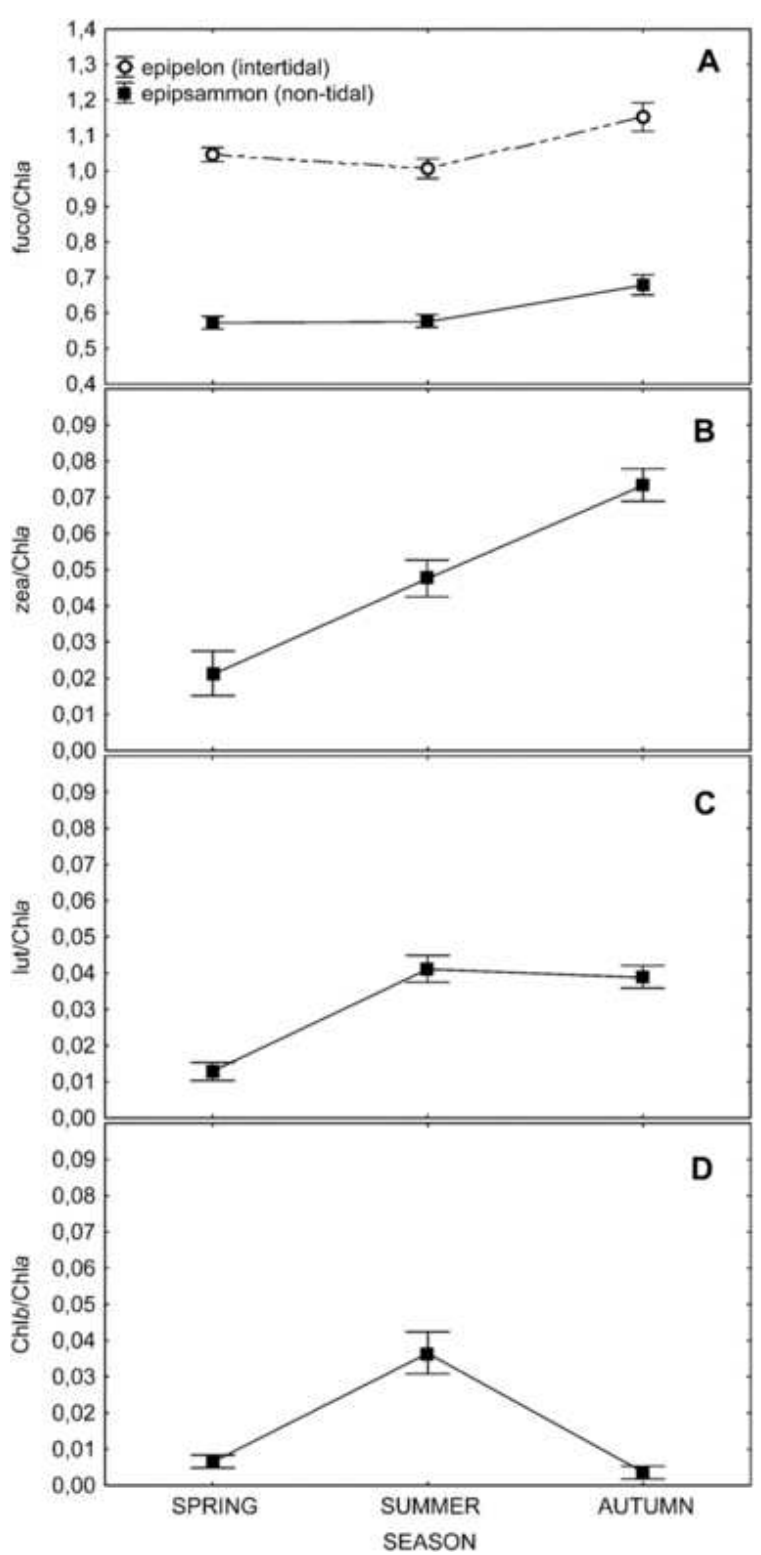

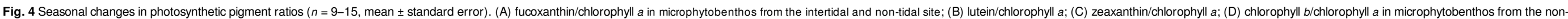
tidal site.

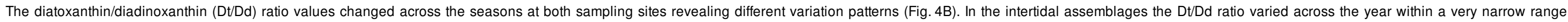

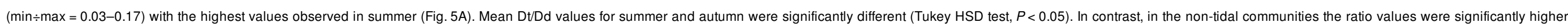
(ANOVA, $P<0.001$ ) and their large, but statistically insignificant, variations were observed ( $\min \div \max =0.35-0.75$; Tukey HSD test, $P>0.05 ;$ Fig. $5 \mathrm{~A}$ ). 


\section{elsevier_YECSS_4596}

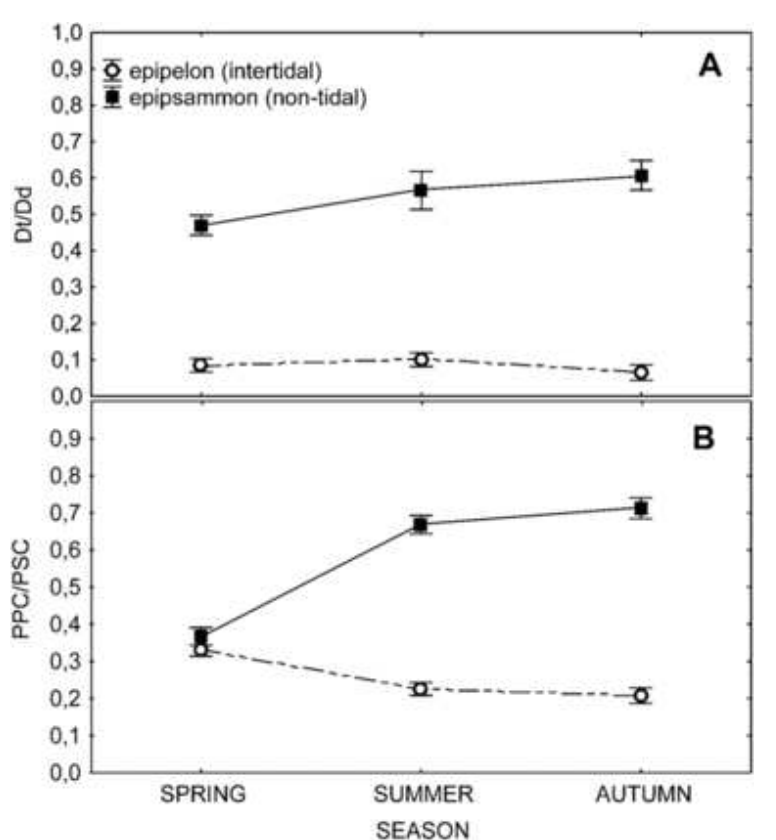

Fig. 5 Seasonal changes in photosynthetic and photoprotective pigments in microphytobenthos from the intertidal and non-tidal site ( $n=9-15$, mean \pm standard error). (A) Diatoxanthin/diadinoxanthin ratio; (B) photoprotective/photosynthetic carotenoids ratio.

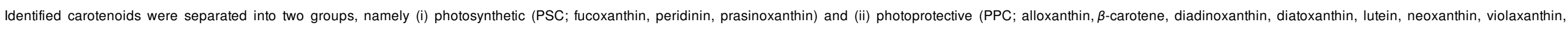

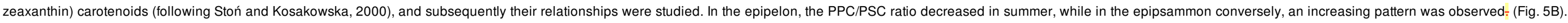
Moreover, there were no statistically significant differences between summer and autumn in the mean ratio values for both microphytobenthos types (Tukey HSD test, $P>0.05$ ).

\subsection{Photosynthetic parameters}

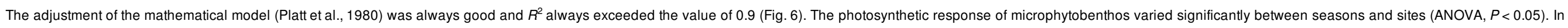

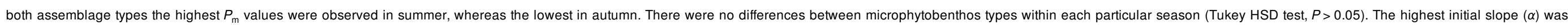

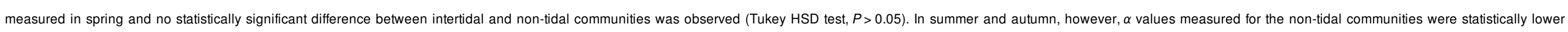

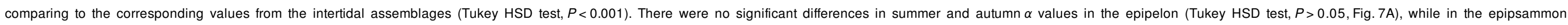

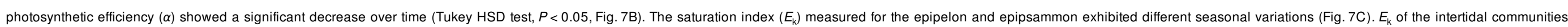

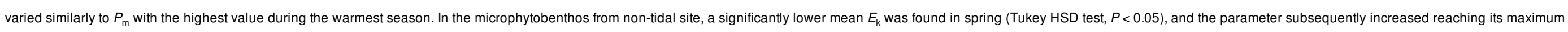
in autumn. During summer and autumn, $P_{\mathrm{m}}$ and $\alpha$ were changing concomitantly $(y=0.00459 x+0.00851, r=0.814, P<0.001)$, therefore no difference between summer and autumn mean $E_{\mathrm{k}}$ values was observed. 
elsevier_YECSS_4596

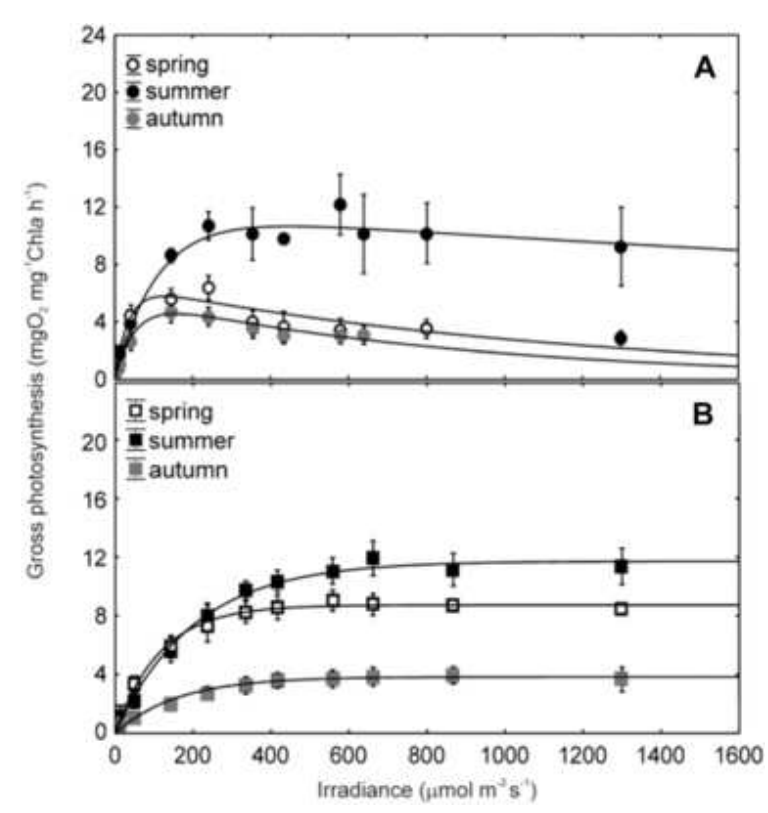

Fig. 6 Seasonal variation in the shape of P-E curves [gross photosynthesis $(n=9-15$, mean \pm standard error) vs. light] in microphytobenthos formfrom the intertidal (A) and non-tidal (B) site.

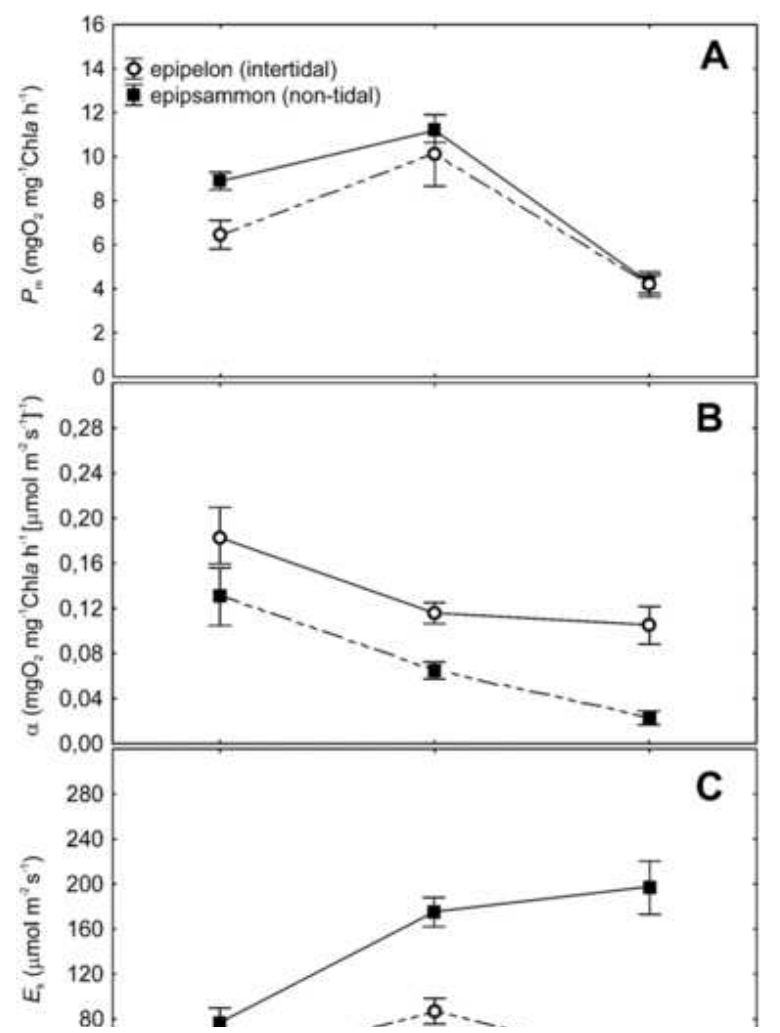




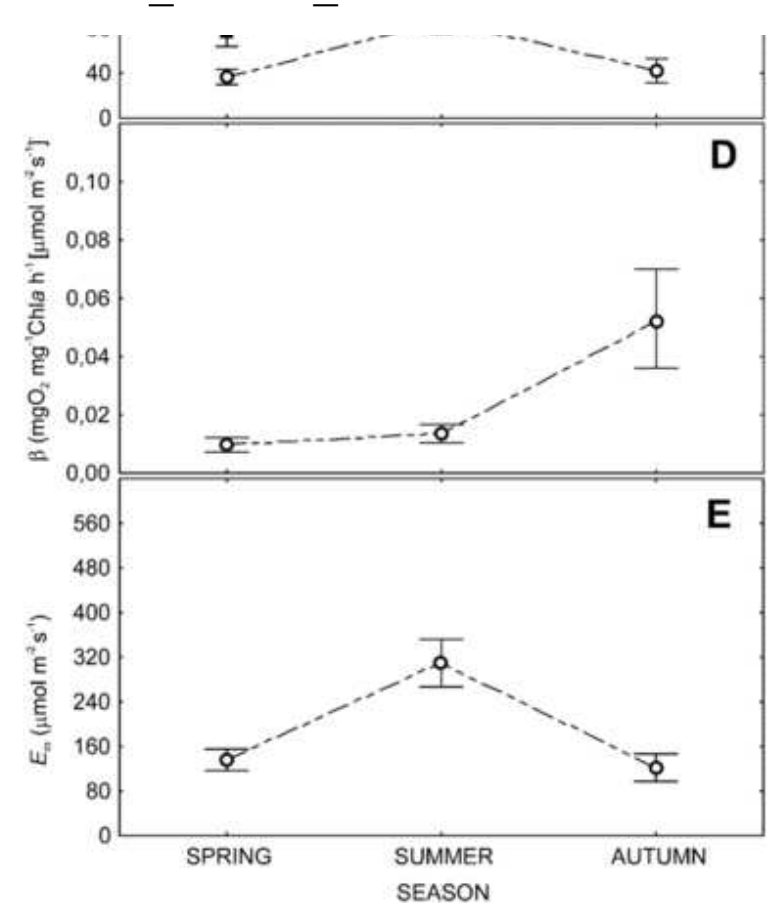

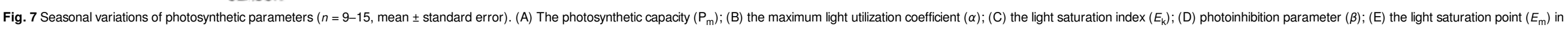
microphytobenthos from the intertidal and non-tidal site.

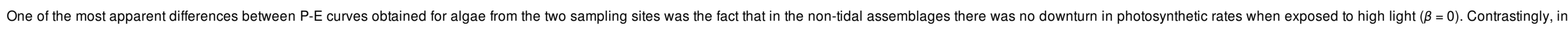

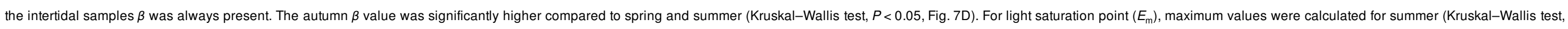
$P<0.05$ ), whereas they were lower for spring and autumn (Fig. 7E).

\section{Discussion}

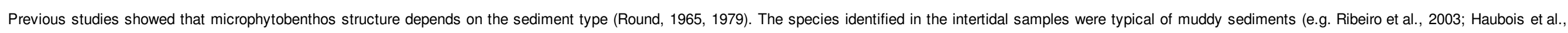

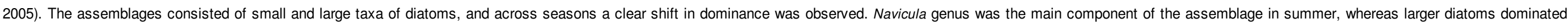

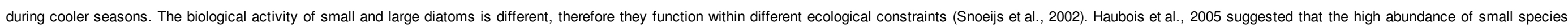

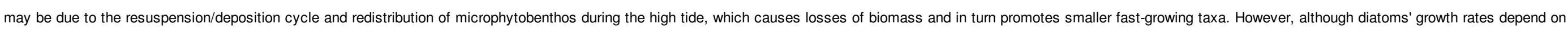

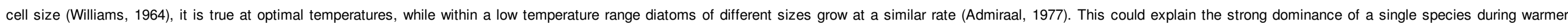

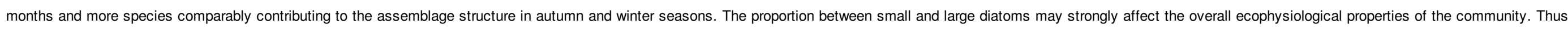
the observed seasonal variability in species dominance may, at least partially explain variations in the photoacclimation of an assemblage.

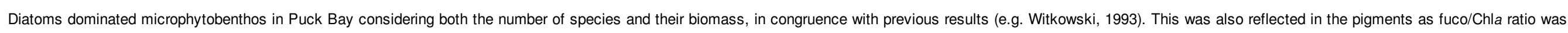

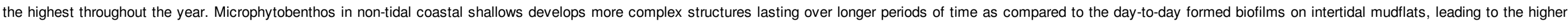

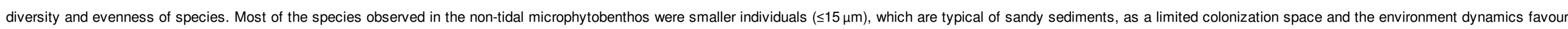

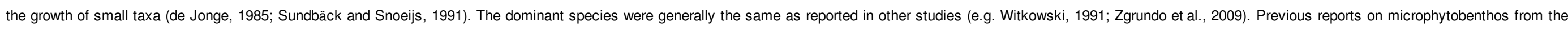

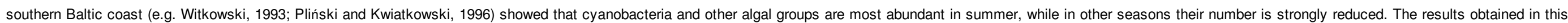
study differ from previous observations showing that the input of non-diatom taxa to the micorphytobethos biomass was constant throughout the year, although with a seasonally changing dominant groups. 


\section{elsevier_YECSS_4596}

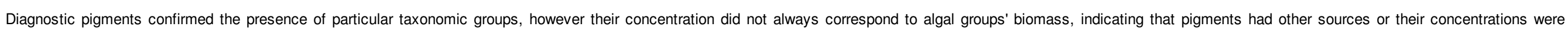

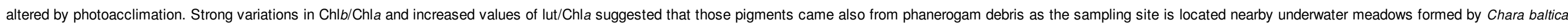

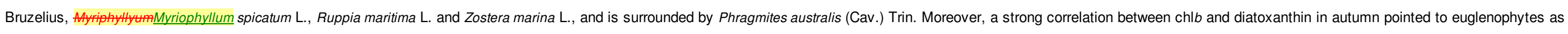
a significant source of the former.

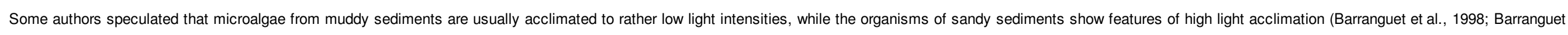

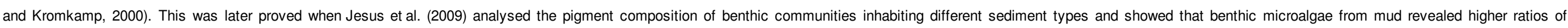

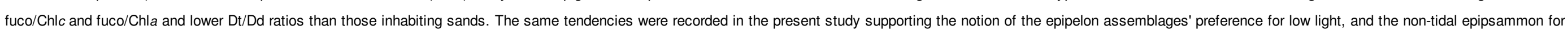
higher irradiances.

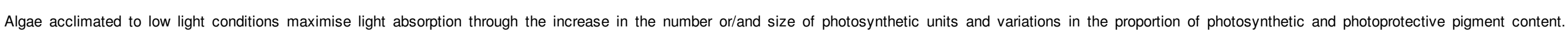

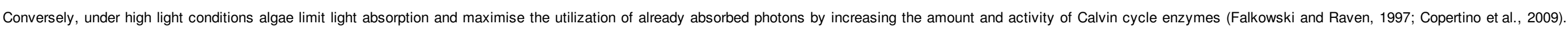

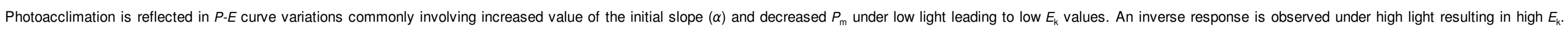

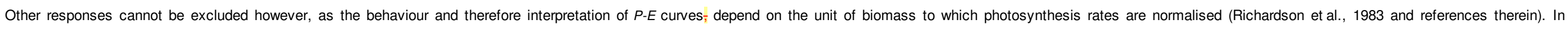
ecological studies, photosynthetic rates are usually expressed on a chlorophyll a basis as it is the most common measure of algal biomass (Maclntyre et al., 2002).

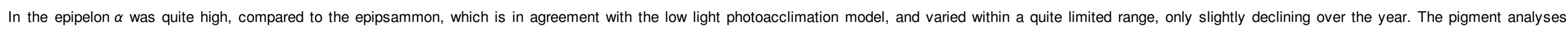

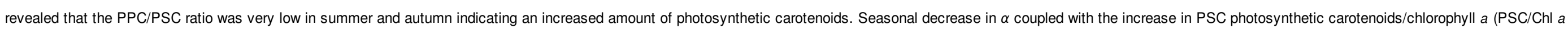

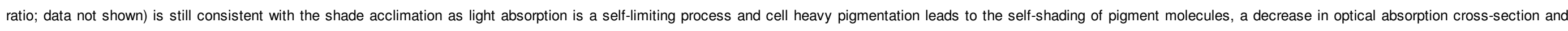

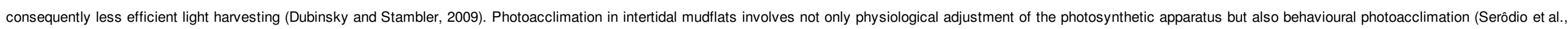

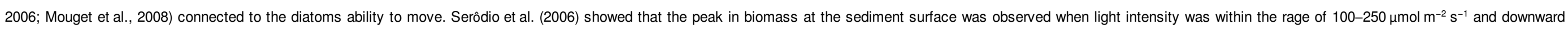

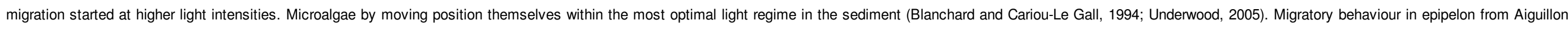

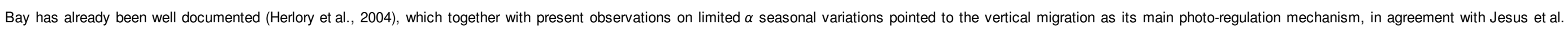
(2009).

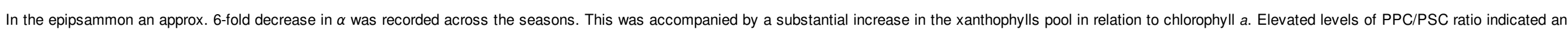

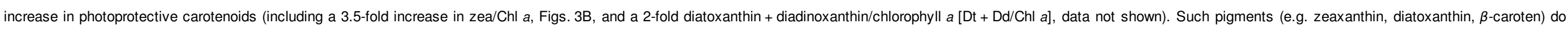

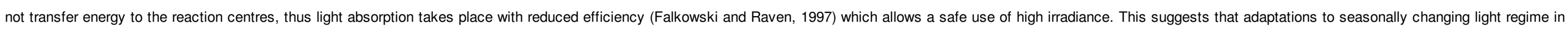

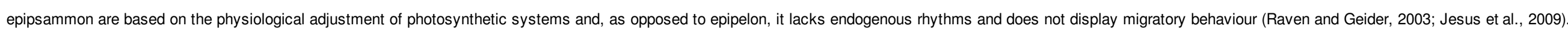

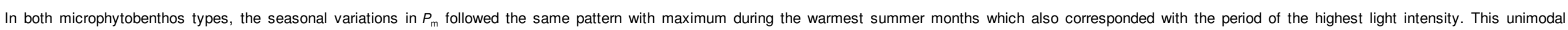

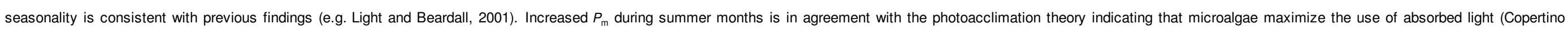
et al., 2009), which is possible due to the increased content of electron transport chain and activity of enzymes involved in carbon metabolism, mainly RUBISCO (Davison, 1991).

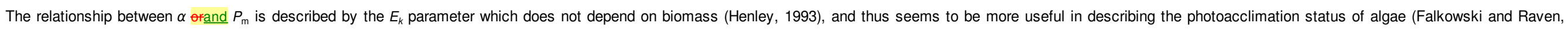
1997; Light and Beardall, 2001).

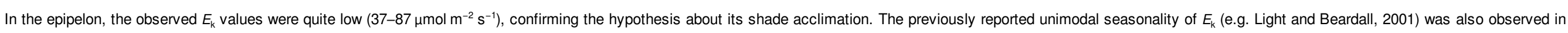

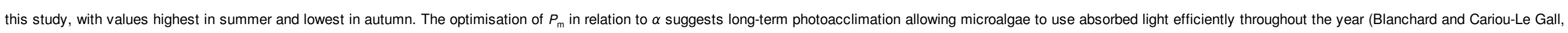

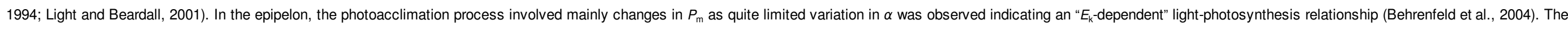

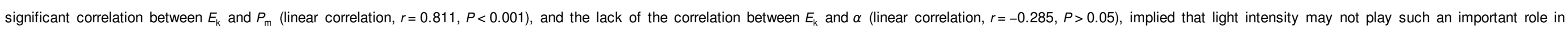
regulating productivity (Guarini et al., 2002). Relatively limited $\alpha$ variations in the intertidal epipelon allow the assumption that the overall primary productivity is controlled mainly by temperature. 


\section{elsevier_YECSS_4596}

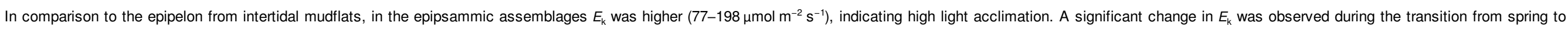

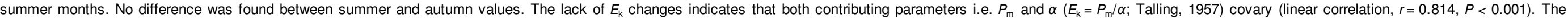

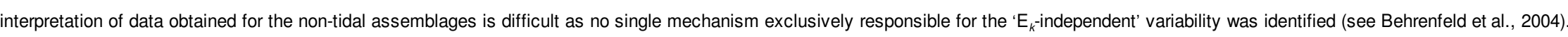

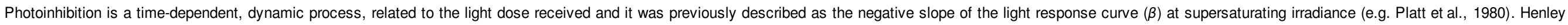

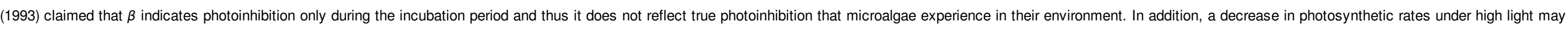

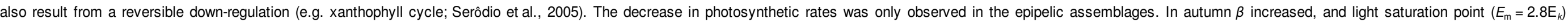

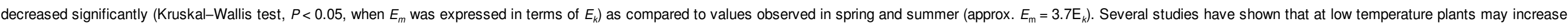

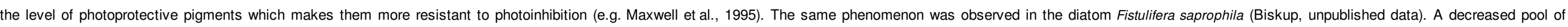

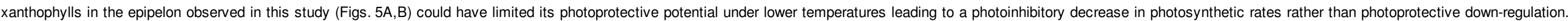

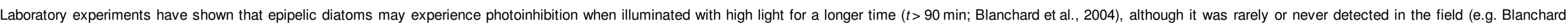

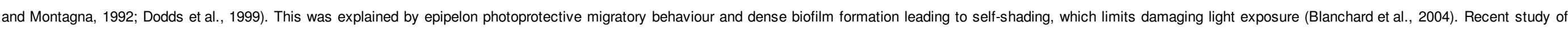

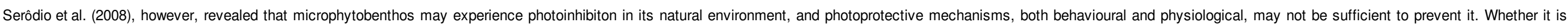
due to the altered physiological state of cells, or structural changes within the biofilm it is still not known.

\section{Conclusions}

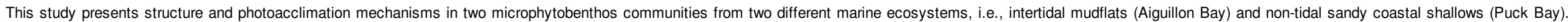

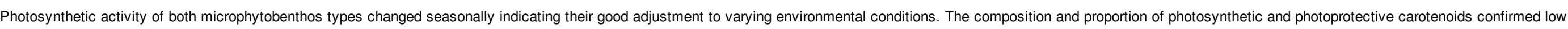

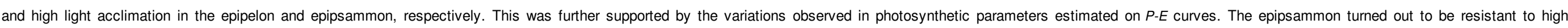

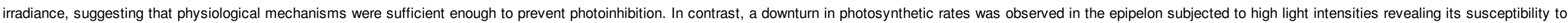

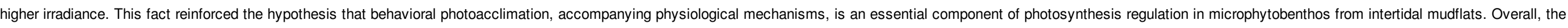

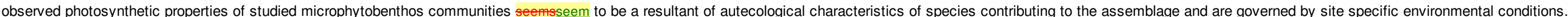

\section{Uncited reference}

Behrenfeld et al., 1998, Woelfel et al., 2007.

\section{Acknowledgements}

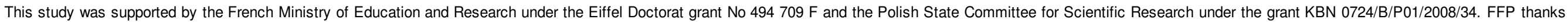
John Breslin for correcting English.

\section{References}

Admiraal W., Influence of light and temperature on the growth rate of estuarine benthic diatoms in culture, Mar. Biol. 39, 1977, 1-9.

Barranguet C. and Kromkamp J., Estimating primary production rates from photosynthetic electron transport in estuarine microphytobenthos, Mar. Ecol. Prog. Ser. 204, 2000, 39-52.

Barranguet C., Kromkamp J. and Peene J., Factors controlling primary production and photosynthetic characteristics of intertidal microphytobenthos, Mar. Ecol. Prog. Ser. 173, 1998, 117-126.

Battarbee R.W., Diatom analysis, In: Berglund B.E., (Ed), Handbook of Holocene Palaeoecology and Palaeohydrology, 1986, Jhon Wiley \& Sons Ltd., 527-570.

Behrenfeld M.J., Prasil O., Babin M. and Bruyant F., In search of a physiological basis for covariations in light-limited and light-saturated photosynthesis, J. Phycol. 40, 2004, 4-25.

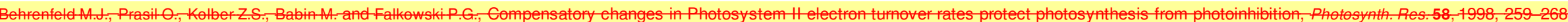

Blanchard G.F. and Cariou-Le Gall V., Photosynthetic characteristic of microphytobenthos in Marennes-Oléron Bay, France: preliminary results, J. Exp. Mar. Biol. Ecol. 182, 1994, 1-14. 


\section{elsevier_YECSS_4596}

Blanchard G.F., Guarini J.-M., Dang C. and Richard P., Characterizing and quantifying photoinhibition in intertidal microphytobenthos, J. Phycol. 40, $2004,692-696$.

Blanchard G.F. and Montagna P.A., Photosynthetic response of natural assemblages of marine benthic microalgae to short- and long-term variations of incident irradiance in Baffin Bay, Texas, J. Phycol. 28 , $1992,7-14$.

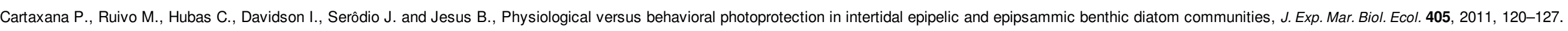

Consalvey M., Paterson D.M. and Underwood G.J.C., The ups and downs of life in a benthic biofilm: migration of benthic diatoms, Diatom Res. 19, $2004,181-202$.

Copertino M.S., Cheshire A. and Kildea T., Photophysiology of a turf algal community: integrated responses to ambient light and standing biomass, J. Phycol. 45, 2009, 324-336.

Cunningham B. and Kirk P.L., A new form of differential micro-respirometer, J. Physiol. 24, 1940, 135-149.

Dahl B. and Blanck H., Use of sand-living microalgal communities (epipsammon) in ecotoxicological testing, Mar. Ecol. Prog. Ser. 144, 1996, 163-173.

Davison I.R., Environmental effects on algal photosynthesis: temperature, J. Phycol. 27, 1991, 2-8.

de Jonge V.N., The occurrence of "epipsammic" diatom populations: a result of interaction between physical sorting of sediments and certain properties of diatom species, Estuar. Coast. Shelf Sci. 21, 1985, 607-622.

Dodds W.K., Biggs B.J.F. and Lowe R.L., Photosynthesis-irradiance patterns in benthic microalgae: variations as a function of assemblage thickness and community structure, J. Phycol. 35, 1999, 42-53.

Dubinsky Z. and Stambler N., Photoacclimation processes in phytoplankton: mechanisms, consequences, and applications, Aquat. Microb. Ecol. 56, 2009, 163-176.

Eaton J.W. and Moss B., The estimation of numbers and pigment contents in epipelic algal populations, Limnol. Oceanogr. 11, 1966, 584-595.

Falkowski P.G. and Raven J.A., Aquatic Photosynthesis, 1997, Blackwell Science; Massachusetts, 375.

Guarini J.-M., Cloern J.E., Edmunds J. and Gros P., Microphytobenthic potential productivity estimated in three tidal embayments of the San Francisco Bay: a comparative study, Estuaries 25 (3), 2002, 409-417.

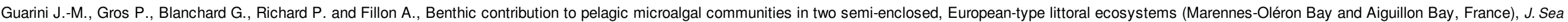
Res. 52, 2004, 241-258.

Hartwig E.O., Factors affecting respiration and photosynthesis by the benthic community of a subtidal siliceous sediment, Mar. Biol. 46, 1978, 283-293.

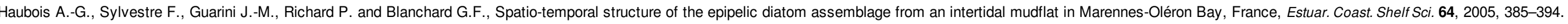
HELCOM, Manual for Marine Monitoring in the COMBINE Programme, 2013

Henley W.J., Measurement and interpretation of photosynthetic light-response curves in algae in the context of photoinhibition and diel changes, J. Phycol. 29, 1993, 729-739.

Herlory O., Guarini J.-M., Richard P. and Blanchard G.F., Microstructure of microphytobenthic biofilm and its spatio-temporal dynamic in an intertidal mudflat (Aiguillon Bay, France), Mar. Ecol. Prog. Ser. 282, 2004, 33-44.

Herlory O., Richard P. and Blanchard G.F., Methodology of light response curves: application of chlorophyll fluorescence to microphytobenthic biofilms, Mar. Biol. 153, 2007, 91-101.

Jankowska H. and Łęczyński L., Osady denne, In: Korzeniewski K., (Ed), Zatoka Pucka, 1993, Fundacja Rozwoju Uniwersytetu Gdańskiego; Gdańsk, 320-327.

Jesus B., Brotas V., Ribeiro L., Mendes C.R., Cartaxana P. and Paterson D.M., Adaptations of microphytobenthos assemblages to sediment type and tidal position, Cont. Shelf Res. 29, 2009, 1624-1634.

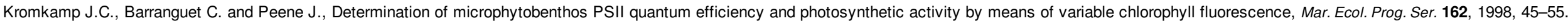

Kühl M., Lassen C. and Jørgensen B.B., Light penetration and light intensity in sand marine sediments measured with irradiance and scalar irradiance fiber-optic microprobes, Mar. Ecol. Prog. Ser. 105, $1994,139-148$.

Light B.R. and Beardall J., Photosynthetic characteristics of sub-tidal benthic microalgal populations from a temperate, shallow water marine ecosystem, Aquat. Bot. 70, 2001, 9-27.

Lorin J., Contribution à l'étude des transits sédimentaires dans la partie orientale duPertuis Breton et la baie de l'Aiguillon, Bull. I'Institut Géologie Bassin d'Aquitaine 5, 1968, 111-139. 


\section{elsevier_YECSS_4596}

Lucas C.H., Banham C. and Holligan P.M., Benthic-pelagic exchange of microalgae at a tidal flat. 2. Taxonomic analysis, Mar. Ecol. Prog. Ser. 212, 2001, 39-52.

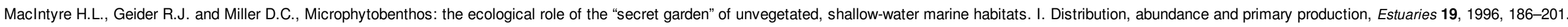

MacIntyre H.L., Kana T.M., Anning T. and Geider R.J., Photoacclimation of photosynthesis-irradiance response curves and photosynthetic pigments in microalgae and cyanobacteria, J. Phycol. 38, 2002, 17-38.

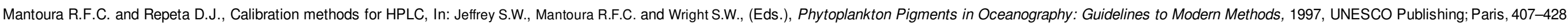
Maxwell D.P., Falk S. and Huner N.P.A., Photosystem II excitation pressure and development of resistance to photoinhibition, Plant Physiol. 107, 1995, 687-694.

Mouget J.-L., Perkins R., Consalvey M. and Lefebvre S., Migration or photoacclimation to prevent high irradiance and UV-B damage in marine microphytobenthic communities, Aquat. Microb. Ecol. 52, 2008, 223-232.

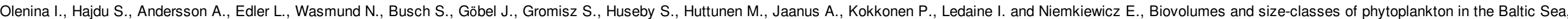
Balt. Sea Environ. Proc. 106, 2006, 144

Platt T., Gallegos C.L. and Harrison W.G., Photoinhibition of photosynthesis in natural assemblages of marine phytoplankton, J. Mar. Res. 38, 1980, 387-701.

Pliński M. and Kwiatkowski J., Microphytobenthos of the shallow littoral of the southern Baltic, Oceanol. Stud. 4, 1996, 65-79.

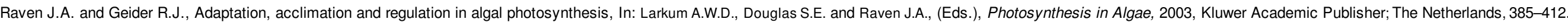
Ribeiro L., Brotas V., Mascarell G. and Couté A., Taxonomic survey of the microphytobenthic communities of two Tagus estuary mudflats, Acta Oecol. 24, 2003, S117-S123.

Richardson K., Beardall L. and Raven J.A., Adaptation of unicellular algae to irradiance: an analysis of strategies, New. Phytol. 93, 1983, 157-191.

Round F.E., The epipsammon a relatively unknown freshwater algal association, Br. Phycol. Bull. 2 (6), 1965, 456-462.

Round F.E., Benthic Marine Diatoms, Oceanography and Marine Biology. Annual Review vol. 9, 1971, 83-139.

Round F.E., A diatom assemblage living below the surface of intertidal sand flats, Mar. Biol. 54, 1979, 219-223.

Round F.E., The Ecology of Algae, 1981, Cambridge University Press; Cambridge, 653

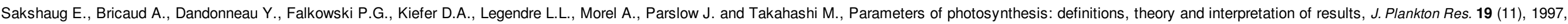
$1637-1670$.

Serôdio J., Cruz S., Vieira S. and Brotas V., Non-photochemical quenching of chlorophyll fluorescence and operation of the xanthophyll cycle in estuarine microphytobenthos, J. Exp. Mar. Biol. Ecol. 326, 2005, 157-169.

Serôdio J., Coelho H., Vieira S. and Cruz S., Microphytobenthos vertical migratory photoresponse as characterised by light-response curves of surface biomass, Estuar. Coast. Shelf Sci. 68, $2006,547-556$.

Serôdio J., Vieira S. and Cruz S., Photosynthetic activity, photoprotection and photoinhibition in intertidal microphytobenthos as studied in situ using variable chlorophyll fluorescence, Cont. Shelf Res. 28, 2008, 1363-1375.

Šesták Z., Jarvis P.G. and Čatsky J., Criteria for the selection of suitable methods, In: Šesták Z., Čatsky J. and Jarvis P.G., (Eds.), Plant Photosynthetic Production. Manual of Methods, 1971 , Publisher, Hague, 257-275.

Snoeijs P., Busse S. and Potapova M., The importance of diatom cell size in community analysis, J. Phycol. 38, 2002, 265-272.

Stoń J. and Kosakowska A., Qualitative and quantitative analysis of Baltic phytoplankton pigments, Oceanologia 42 (4), 2000, 449-471.

Strickland I.D.H. and Parsons T.R., A Practical Handbook of Seawater Analysis, 1972, Fisheries Research Board of Canada; Ottawa, 310.

Sundbäck K., The response of shallow-water sediment communities to environmental changes, In: Krumbien W.E., Paterson D.M. and Stal L.J., (Eds.), Biostabilization of Sediments, 1994, Verlag; Oldenburg, 17-40.

Sundbäck K., Miles A. and Linares F., Nitrogen in nontidal littoral sediments: role of microphytobenthos and denitrification, Estuaries Coasts 29 (6B), $2006,1196-1211$.

Sundbäck K. and Snoeijs P., Effects of nutrient enrichment on microalgal community composition in a coastal shallow-water sediment system: an experimental study, Bot. Mar. 34, 1991, 341-358. 


\section{elsevier_YECSS_4596}

Sutherland T.F., Grant J. and Amos C.L., The effect of carbohydrate production by the diatom Nitzschia curvilineata on the erodibility of sediment, Limnol. Oceanogr. 43, $1998,65-72$.

Talling J.F., The phytoplankton population as a compound photosynthetic system, New. Phytol. 56, 1957, 133-149.

Underwood G.J.C., Microalgal (microphytobenthic) biofilms in shallow coastal waters: how important are species?, Proceeding Calif. Acad. Sci. 56 (15), $2005,162-169$.

Underwood G.J.C. and Kromkamp J., Primary production by phytoplankton and microphytobenthos in estuaries, Adv. Ecol. Res. 29, 1999, 93-153.

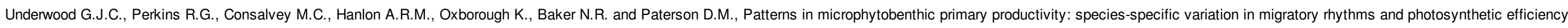

in mixed-species biofilms, Limnol. Oceanogr. 50 (3), 2005, 755-767.

Williams R.B., Division rates of salt marsh diatoms in relation to salinity and cell size, Ecology 45 (4), 1964, 877-880.

Witkowski A., Diatoms of the Puck Bay coastal shallows (Poland, Southern Baltic), Nordic J. Bot. 11, 1991, 689-701.

Witkowski A., Mikrofitobentos, In: Korzeniewski K., (Ed), Zatoka Pucka, 1993, Fundacja Rozwoju Uniwersytetu Gdańskirgo; Gdańsk, 395-415.

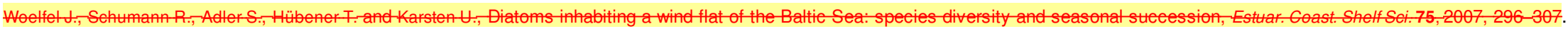

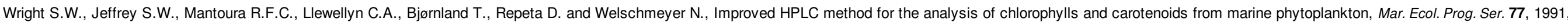
183-196.

Zgrundo A., Dziengo-Czaja M., Bubak I. and Bogaczewicz-Adamczak B., Studies on the biodiversity of contemporary diatom assemblages in the Gulf of Gdańsk, Oceanol. Hydrobiological Stud. 37, $2009,139-153$.

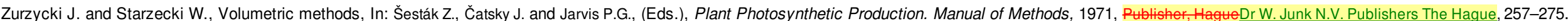

\section{Queries and Answers}

Query: Please check the country name retained in affiliation 'a' and correct if necessary.

Answer: Corrected in the text. 'Poland' changed into 'Polska'

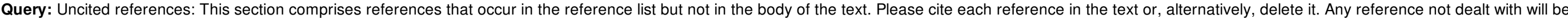
retained in this section.

Answer: Uncited references were removed from the reference list.

Query: Please confirm that given names and surnames have been identified correctly.

Answer: Yes 